\title{
BASIC CONCEPTS OF COGNITIVE LINGUISTICS
}

\author{
Shokhida Inatovna Shodieva
}

Lecturer Department of Distance Education in Social Science and Humanities Jizzakh State Pedagogical Institute Jizzakh, Uzbekistan

\section{ABSTRACT}

This article discusses the basic concepts of cognitive linguistics. This lays the groundwork for a deeper understanding of the nature of language and thinking, language and mind connections in linguistic research. Cognitive linguistics is a linguistic field that to some extent unites the research conducted in these areas. This science involves cognitive processes, also known as cognition related to knowledge and information, for the application of special applications. This requires a clear definition of the content of Uzbek cognitive linguistics, its relationship with other disciplines, the development of specific methods of research and analysis.

KEYWORDS: - Cognitive linguistics, concepts, groundwork, understanding, nature of language, thinking, connections, linguistic research, linguistic field, cognitive processes, cognition, knowledge, information.

\section{INTRODUCTION}

In recent years, scientists have been consistently engaged in the analysis of human linguistic thinking and communication activities. On this basis, in modern linguistics, sociolinguistics, which studies the relationship between society and human speech, pragmatics, which discusses the relationship between linguistic units and speech of a particular subject, ethnolinguistics, which studies the national-ethnic aspects of speech, areas such as comprehension and cognition, the purpose of speech, and the role and importance of communicative situations in psycholinguistics have emerged. This lays the groundwork for a deeper understanding of the nature of language and thinking, language and mind connections in linguistic research. Cognitive linguistics is a linguistic field that to some extent unites the research conducted in these areas.

Cognitive approach to the analysis of linguistic phenomena in linguistics helps to form different structures of knowledge and identify their manifestations in language by categorizing and conceptualizing the problems of language and thinking, the relationship of word meaning.

\section{THE MAIN FINDINGS AND RESULTS}

Cognitology is the science of knowledge and thinking, the results of the study, understanding, and perception of existence and its objective laws, and it has become a specific system of collected information that is located in our minds 
CURRENT RESEARCH JOURNAL OF PEDAGOGICS 2(12): 156-161,

December 2021 DOI: https://doi.org/10.37547/pedagogics-crjp-02-12-31

ISSN 2767-3278

(C)2021 Master Journals

Crossref do: 81 Google

Accepted 24th December, 2021 \& Published 29th December, 2021

in a certain way and by its nature is composed of cognitive processes. Cognitive science also includes the study of the processes of the structure of knowledge, the processing, storage, use, organization and collection of various information, including the study of the formation of these structures in the human brain. The content of cognitive linguistics can be defined as follows:

The object of study of cognitive linguistics is language. This science studies language as "a means of forming and expressing thoughts in the human mind, storing and organizing knowledge" [1.18]. Indeed, language is the basis of cognitive activity. As A.V. Kravchenko rightly points out, language is "an integral part of cognition and reflects the interaction of cultural, spiritual, communicative, functional factors" [2.37].

Based on the ideas of NN Boldyrev, it can be said that the main goal of cognitive linguistics is "to penetrate into the various structures of knowledge through the study of language and to explain the language and the relationships between them" [1.23].

The main task of cognitive linguistics is to determine the role of the language system in the study and understanding of the environment, human history and culture, customs, to organize the accumulated knowledge based on existing experience in the human mind, to study the role of language as a mediator [3.175]. The purpose of these interrelated, complementary directions is to determine the role and capabilities of linguistic means in the realization of human speech and its communicative qualities, communication, message, influence, etc.

Linguists acknowledge that this science discusses the general principles of mental processes in the human brain, management, and the way it thinks about cognitive processes, categorization, classification, how knowledge growth takes place, information-related activity systems [4.8].

Thus, cognitive science is an independent field of knowledge that studies how a person receives, processes, and uses information.

As E.S. Kubryakova points out, cognitive science serves as an "umbrella" term for scientific disciplines dealing with the problems of thinking, knowing, storing and processing information. She notes that it combines fields such as cognitive psychology, cognitive linguistics, philosophical theory of cognition, logical analysis of language, artificial intelligence theory, neurophysiology, and that cognitive anthropology, cognitive sociology, and even cognitive literature have been formed today. This science involves cognitive processes, also known as cognition related to knowledge and information, for the application of special applications. Cognition is the ability of a subject to know, comprehend, describe [5.35]. According to N.N. Boldirev: "Cognition is any conscious or unconscious process of acquiring, processing, remembering, restoring and using information. It combines the following psychological processes: 1) perception of the world; 2) observation; 3) categorization; 4) contemplation; 5) speech; 6) imagination and etc." [1.23]

It seems that in modern linguistics the anthropocentric principle is manifested in concrete expressions of various private forms and is associated with the study of a wide range of linguistic phenomena reflected in the linguistic consciousness of the speaker. In cognitive linguistics, human speech activity is related to: 1) language and human spirituality; 2) language, thinking and human consciousness; 3) human physiology and language; 4) language and culture; 5) language and communication; 6) the existence of problems such as language and human dignity [6.22-31].

The growing attention to the human factor, personality and language relations paves the way 
CURRENT RESEARCH JOURNAL OF PEDAGOGICS 2(12): 156-161,

December 2021 DOI: https://doi.org/10.37547/pedagogics-crjp-02-12-31

ISSN 2767-3278

(C)2021 Master Journals

Crossref do: 81 Google

Accepted 24th December, 2021 \& Published 29th December, 2021

for the formation of new concepts and categories of cognitive linguistics, understanding the facts of reality, understanding the causes of events, analyzing them from a linguistic point of view. This requires a clear definition of the content of Uzbek cognitive linguistics, its relationship with other disciplines, the development of specific methods of research and analysis.

The formation of cognitology as a science is associated with the changes that have taken place in the social life of the people in the last century, the achievements in science and technology. In the 50s of the XX century, the creation of electronic computers and automated control systems based on them led to the origin and development of cognitive science. The migration of scientists from many countries to the United States due to the Second World War and the achievement of certain achievements in this science played an important role in the development of cognitive science.

Advances in cognitive science were particularly evident in the 1960s. Psychologist J. Miller, linguist $N$. Khomsky tried to explain the connection between psychology and linguistics [7.7]

A person's accumulated knowledge of objective reality is manifested in speech activities in the form of speech, scientific, formal, journalistic, and artistic discourse. Therefore, human speech activity has also gradually become the subject of scientific research in the $60 \mathrm{~s}$ of the last century in the cognitive direction. Research in this area has looked at language as a cognitive tool that symbolizes the system of signs, the transformation and coding of messages, the structure of memory and the process of searching and activating information in it, artificial intelligence and similar issues.

According to sources, this trend was formed in the second half of the 1970s, when the term cognitive linguistics was introduced into scientific circulation in 1975 by J. Lakoff and G. Thompson [8.248]. In 1989, a scientific conference on current issues in the field was held in Duisburg (Germany), at which the Association of Cognitive Linguistics was established. Cognitive grammar of R. Leneker, many works of L. Telli, researches of J. Lakoff and M. Jensone, works by J. Fokonen laid the foundation for the consolidation and development of cognitive linguistics as a separate field [5,6]. By the end of the last century, schools specializing in cognitive linguistics had emerged in various countries around the world. The Emergence of Modern Cognitive Linguistics American Linguists J. Lakoff, Ronald Langaker, Ray Jakendoff, and others. In Russia at this time, the theory of the essence of the word was considered on the basis of component analysis. Yu.D. Apresyan, I.A. Melchuk, discovered by A.K. Jolkovsky, semantic measurements allowed to identify the primary elements, to begin to compile semantic dictionaries. These primary elements, which are listed as categories in the works of American authors, lie within the framework of human cognitive activity. The work of Polish researcher Anna Vejbitskaya in this regard should also be noted. Although both directions have developed independently and different terms have been used, the categories revealed by the research are in many respects intertwined. The existence of a correspondence between the terms used by American cognitive linguists and the Moscow school of semantics Yu.D. Apresyan is shown in the works of E.V. Rakhilina [9.274-323;3-15].

Cognitive linguistics has entered a new phase in the study of the complex relationship of language and consciousness [10.3]. Such studies were initiated by neurophysiologists, physicians, psychologists (P. Broka, K. Vernike, I.M. Sechenov, V.M. Bekhterev, I.P. Pavlov, etc.). On the basis of neurophysiology, a branch of neurolinguistics has emerged that identifies the fact that linguistic activity takes place in the 
CURRENT RESEARCH JOURNAL OF PEDAGOGICS 2(12): 156-161,

December 2021 DOI: https://doi.org/10.37547/pedagogics-crjp-02-12-31

ISSN 2767-3278

(C)2021 Master Journals

Crossref do: 81 Google

Accepted 24th December, 2021 \& Published 29th December, 2021

human brain and that its actions such as speaking, hearing, reading and writing are directly related to different parts of the brain [11.320].

The next stage of the problem of the relationship between language and consciousness is psycholinguistics, in which the processes of the birth of speech and the study of language as a system of signs stored in the human mind, the language system and its application, functions are studied. Such studies were conducted by American psycholinguists Ch. Osgud, T. Sebeok, Dj. Greenberg, Dj. Carroll and Russian scientists A.A. Leontev, I.N. Gorelov, A.A. Zalevskaya, Yu.N. Karaulov and others.

At the end of the XX century, a number of works in this direction were devoted to the analysis of discourses [12].

In recent years, research has been created to interpret the subject and categories of cognitive linguistics from different perspectives [13]. In defining the categories of cognitive linguistics, scholars have identified new directions in the study of language as a system and in speech phenomena. In the study of word formation, cognitive approaches have been developed in identifying grammatical categories [14]. Cognitive research has also been conducted in Uzbek linguistics to determine the nature of linguistic phenomena [15.67]. If we look at the significant achievements in the field of world linguistics, it becomes clear that cognitive linguistics is a completely new field for Uzbek linguistics. Today in Uzbek linguistics some work in this direction has begun. Since research in the field of cognition in Uzbek linguistics has just begun, each research in this area has a certain scientific and practical significance. In Uzbek linguistics, there are scientific studies that approach the discovery of the essence of linguistic phenomena from a cognitive point of view. This indicates that Uzbek linguistics is making some progress in this area as well. In particular, prof. It is safe to say that Safarov's book on cognitive linguistics has become a swallow of research in this area [15.86]. In addition, scientists such as $0 . \mathrm{K}$ Yusupov, S.Muhamedova, K.Nazarov, A.Juraev also published articles on the problems of cognitive linguistics [16.22].

In linguistics, language units with mental properties are understood as a system of signs, through which a person gradually understands the features of the objective world around him, assimilates the facts of reality. In this case, the manifestation of language in its social functions requires the direct executor - human participation. As S. Mukhamedova rightly points out, "in traditional linguistics, the focus was mainly on the plan of expression and content of the sign, and the person who was the realizer of the communication process was left out of the eyes of researchers" [17.189-191]. The difference between modern linguistics and traditional linguistics is that in revealing the essence of linguistic phenomena, special attention is paid not to the plan of expression and content of the sign, but to the human factor that carries out this process, the place of man in this process. Cognitive linguistics, on this basis, aims to store the national-cultural, spiritualphilosophical, encyclopedic, logical knowledge of the human mind and the means that enable them to be expressed through oral and written form the study of language in connection with consciousness, and linguistic research is based on this.

Unlike other rules of certain cognitive sciences, this linguistics analyzes human-specific cognitive structures and processes. First of all, it is necessary to systematically classify and interpret the mechanism of human language acquisition and the principles of the structure of linguistic knowledge. Accordingly, cognitive linguistics focuses on the study of the following: 
CURRENT RESEARCH JOURNAL OF PEDAGOGICS 2(12): 156-161,

December 2021 DOI: https://doi.org/10.37547/pedagogics-crjp-02-12-31

ISSN 2767-3278

(C)2021 Master Journals

Crossref doi) 81 Google

Accepted 24th December, 2021 \& Published 29 ${ }^{\text {th }}$ December, 2021

1. The acquisition of language and the principles of its structure, as well as the manifestation of mental characteristics.

2. Cognitive interpretation of the use of language units.

3. Cognitive mechanism of perception.

In cognitive linguistics, one of the key issues is to describe and interpret the internal cognitive structure and dynamics of the speaker or speechoriented individual. The tasks of cognitive linguistics include not only the systematic representation of linguistic phenomena, but also the study of this system and the introduction of its basic principles. It is important for a cognitive linguist to understand what mental representation of linguistics should be and how this knowledge is cognitively processed and what "cognitive truth" is [18.22]. According to S. Mukhamedova, today there are the following main directions of cognitive linguistics: 1) Biological theory of knowledge; 2) Biocultural theory of knowledge; 3) The theory of artificial intelligence; 4) The direction of cognitive semantics [17.189-191].

In the formation of cognitive linguistics, research in linguistics in the field of semiotics, semiotics grammar, logical analysis, speech thinking, onomasiology, psychology, hermeneutics has served as a scientific theoretical basis.

\section{Conclusion}

So, modern cognitive linguistics is a branch of linguistics that studies the cognitive structure of language tools. Linguistic analysis in this direction provides specific scientific information about the cognitive structures in the human mind.

\section{REFERENCES}

1. Boldyrev N.N. Conceptual space of cognitive linguistics // Questions of cognitive linguistics. -Tambov, 2004. P.18;23

2. Kravchenko A.V. Cognitive linguistics today: integration processes and the problem of the method // Questions of cognitive linguistics. -Tambov, 2004. P.37.

3. Irisqulov M.T. Introduction to Linguistics.Tashkent: New Century Generation, 2009. P. 175.

4. Boldyrev N.N. Cognitive Semantics: A Course of Lectures in English Philology. Tambov, 2001. -P.8.

5. Kubryakova E.S. The initial stages of the formation of cognitivism: linguistics psychology - cognitive science // VYa № 4.1994.-P. 35.

6. Kubryakova E.S. The language of space and the space of language. (to the problem statement) // Izv. RAS - SLYa - 1997. No. 3.-P. 22-31.

7. Kubryakova E.S. On the attitudes of cognitive science and actual problems of cognitive linguistics // Questions of cognitive linguistics. \# 1. 2004. -P.7.

8. Starichenok V.D. The Big Linguistic Dictionary. Rostov-on-Don: - Phoenix, 2008. -P. 247-248.

9. Rakhilina E.V. Cognitive semantics: history, personalities, ideas, results // Semiotics and informatics. - Issue 36. - Moscow: 1998. - P. 274-323; Rakhilina E.V., On tendencies in the development of cognitive semantics, Izv. RAS - SLYA - 2000, № 3. - P. 3-15.

10. Popova Z. D., Sternin I. A. Essays on cognitive linguistics. - Voronezh, 2003.-P. 3.

11. Vygotsky L.S. Thinking and speaking. - 
CURRENT RESEARCH JOURNAL OF PEDAGOGICS 2(12): 156-161,

December 2021 DOI: https://doi.org/10.37547/pedagogics-crjp-02-12-31

ISSN 2767-3278

(C)2021 Master Journals

Crossref do: 81 Google

Accepted 24th December, 2021 \& Published 29th December, 2021

Moscow: 1999.-352 P; Luria A.R. Basic problems of neurolinguistics. - Moscow: 1976.; Luria A.R. Language and Consciousness. / Edited by E. D. Chomskaya. -Moscow: Publishing house Mosk. un-ta, 1979 - P. 320.

12. Kibrik A.A. Cognitive research on discourse // VYa. 1994, No. 5; Tsurikova L.V. Cognitive Analysis of Sociopragmatic Aspects of Discourse // Cognitive Semantics: Proceedings of the Second International School-Seminar on Cognitive Linguistics. Tambov, 2000.

13. Belyaevskaya E.G. Cognitive foundations of studying the semantics of a word // Structures of knowledge representation in language. Moscow: 1994; Khudyakov A.A. Concept and meaning // Language personality: cultural concepts. VolgogradArkhangelsk, 1996; Boldyrev N.N. Cognitive Semantics: A Course of Lectures in English Philology. Tambov, 2001; Boldyrev N.N. Conceptual space of cognitive linguistics // Questions of cognitive linguistics. No. 1, 2004.

14. Boldyrev N.N. Systemic and functional connections of linguistic units as a result of the categorizing activity of linguistic consciousness // Connections of linguistic units in the system and implementation. Interuniversity. Sat. scientific. tr. Tambov,1998.

15. Safarov Sh. Cognitive linguistics. -Jizzakh: Sangzor,2007. P. 67;86.

16. Yusupov O. About cognitive linguistics // Collection of scientific articles "Ayub Gulyamov and problems of Uzbek linguistics". - Tashkent: National University of Uzbekistan,2007. P. 22.

17. Muhamedova S. Cognitive linguistics: origin, basic concepts and directions //
Problems of system-structural linguistics (Materials of the Republican scientifictheoretical conference dedicated to the 70th anniversary of NK Turniyazov) .Samarkand, 2010. Pages 189-191.

18. Demyankov V.Z. Cognitive linguistics as a kind of interpretive approach // VYa № 4, 1994. - P.22. 